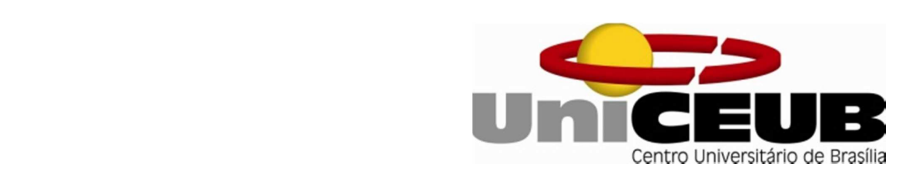

CENTRO UNIVERSITÁRIO DE BRASÍLIA - UniCEUB FACULDADE DE CIÊNCIAS JURÍDICAS E SOCIAIS - FAJS

PROGRAMA DE INICIAÇÃO CIENTÍFICA

ALICE MENEZES GASHTI

A RELEVÂNCIA DE ZOROASTRO PARA AS CONCEITUAÇÕES PÓS-HEGEMÔNICAS DA ORDEM MUNDIAL 


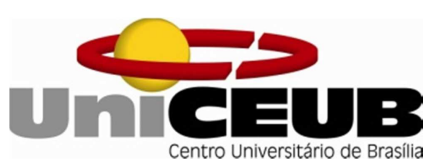

ALICE MENEZES GASHTI

\section{A RELEVÂNCIA DE ZOROASTRO PARA AS CONCEITUAÇÕES PÓS-HEGEMÔNICAS DA ORDEM MUNDIAL}

Relatório final de pesquisa de Iniciação

Científica apresentado à Assessoria de PósGraduação e Pesquisa pela Faculdade de Ciências Jurídicas e Sociais - FAJS.

Orientação: Raphael Spode 


\title{
RESUMO
}

\section{A RELEVÂNCIA DE ZOROASTRO PARA AS CONCEITUAÇÕES PÓS- HEGEMÔNICAS DA ORDEM MUNDIAL}

\author{
Alice Menezes Gashti - UniCEUB, PIC Institucional, aluno bolsista \\ alicegashti@gmail.com
}

Raphael Spode - UniCEUB, professor orientador

raphael.spode@gmail.com

A presente pesquisa objetiva resgatar o pensamento e a doutrina de Zoroastro, sábio, legislador e poeta da Pérsia antiga. Esse movimento de resgate faz parte de uma tendência, em Relações Internacionais, de retornar ao passado em busca de alternativas, novas maneiras de ver e interpretar o mundo social e político. Diante dos dilemas éticos e morais vivenciados pela presente geração, os apelos em torno da renovação da ordem social e política exigem uma investigação da própria sociedade, em busca da compreensão de possibilidades emancipatórias contidas nela mesma, apesar de suas construções patológicas, muitas delas elaboradas em formas de dominação. A crença é de que em meio às ideias vitoriosas no tempo houveram doutrinas silenciadas: elas jazem parcialmente ocultas sob as edificações teórico-filosóficas vigentes. Assim, devese buscar, numa revisão da edificação civilizacional, possíveis etapas que ofereciam outras saídas e alternativas para a humanidade; mas, vencidas, ficaram depositadas nas camadas do tempo. O desafio, portanto, é empreender uma "arqueologia do saber" para reencontrar, nos fundamentos da civilização vigente, tendências culturais, intelectuais, religiosas, sociais, políticas e econômicas, capazes de eliminar um ou outro abuso. Dentre as várias contribuições e tradições espalhadas pelo mundo, é possível imaginar antigas civilizações, tais como a Pérsia, como um repositório de importantes reflexões sobre moralidade, sociedade, política e economia. Nela, encontra-se o Zoroastrismo, uma doutrina que desempenhou um importante papel no desenvolvimento de regiões consideradas como o berço de nossa civilização atual. O Zoroastrismo busca, por meio de uma metafísica, observar a natureza, os indivíduos e suas relações para sugerir um guia de ação cujo propósito é preveni-los dos males existenciais. Nesse espírito, essa pesquisa pretende conhecer os fundamentos ontológicos da doutrina de Zoroastro, nos seus próprios termos culturais e históricos, com a finalidade de repensar, mais tarde, e criticamente, os nossos pressupostos, assumidos, muitas vezes, como "verdades" em teorias vigentes da sociedade e das Relações Internacionais. Do ponto de vista das Relações Internacionais, a pesquisa se insere num movimento metodológico mais abrangente de releitura de obras clássicas que tem por objetivo recuperar valores éticos e religiosos em tempos de crise e perturbação moral.

Palavras-Chave: Teoria das Relações Internacionais. Teoria Crítica. Zoroastrismo. 


\section{SUMÁRIO}

INTRODUÇÃ

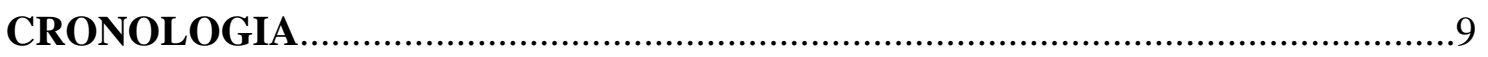

CAPÍTULO 1 - O CONTEXTO HISTÓRICO.........................................................11

1.1 O MUNDO PAGÃO ANTECEDENTE A ZOROASTRO.................................11

ZOROASTRO E A DIFUSÃO DA DOUTRINA.............................................. 12

1.3 HERANÇA DO PERÍODO INDO-IRANIANO DIFUNDIDO NO

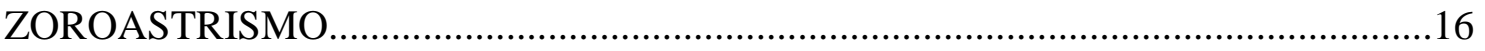

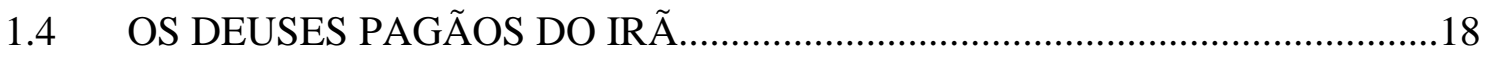

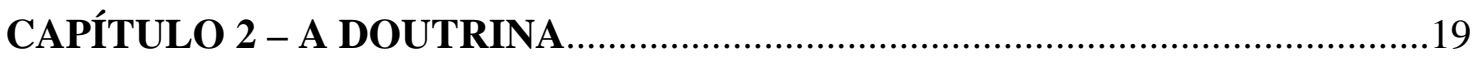

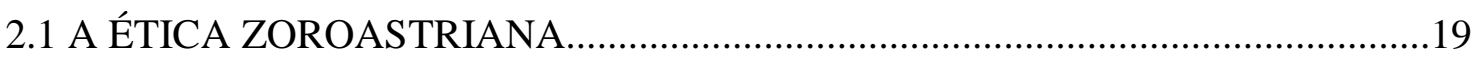

2.2 O SIGNIFICADO DO PRINCÍPIO DE BONS PENSAMENTOS........................20

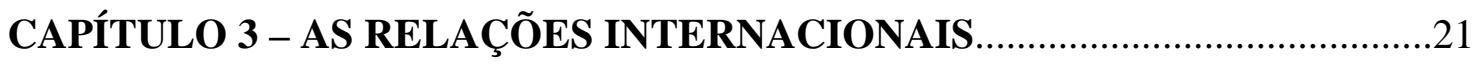

3.1 O ZOROASTRISMO NA GEOPOLÍTICA DO MUNDO ATUAL.........................21

3.2 O ZOROASTRISMO E A TEORIA DAS RELAÇÕES INTERNACIONAIS.......26

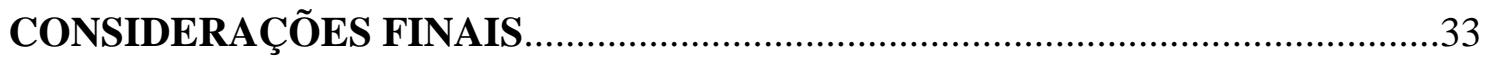

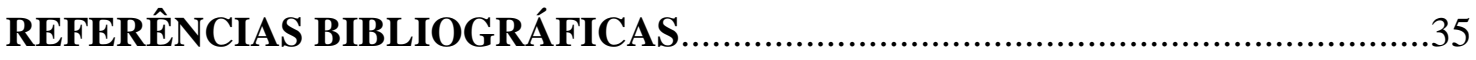




\section{INTRODUÇÃO}

É inegável que as teorias de relações internacionais são, em certo sentido, compostas por aspectos ideológicos. Majoritariamente, as grandes correntes de pensamento internacional quando interpretadas por um olhar crítico denotam conter um pendor, uma visão provinciana e parcial da realidade. Apesar de toda teoria pretender ser universal, a verdade é que elas, em certo sentido, são apenas a expressão de uma visão particular de mundo e, portanto, expressões reduzidas e culturalmente tendenciosas (BURCHILL, 1996; ROCHA, 2002, caps. 1 e 2). Talvez o que exista nas Relações Internacionais seja uma dominância teórica, isto é, uma dominação epistemológica e empírica de conhecimento produzida por uma classe vigente, hegemônica, ocidental. É essa a constatação feita por Robert Cox, por exemplo, ao propor a necessidade de uma transcendência em Relações Internacionais. Essa transcendência iniciaria com a superação da hegemonia conceitual prevalecente no campo de estudos, rumo aquilo que Cox denomina de uma "pós-hegemonia" (SMITH, 1996).

O ponto de partida para compreender de forma concisa o conceito de póshegemonia é entender o que é hegemonia e como o pensamento hegemônico atua tanto no sistema internacional quanto na teoria. Por hegemonia, Robert Cox entende o seguinte:

O termo hegemônico, no que se refere às relações internacionais convencionais, com o sentido do relacionamento entre um Estado dominante e outros menos poderosos, situação que chamo de dominância. [...] o termo hegemon se refere ao Estado dominante, na relação de dominância (COX, 2000).

Apesar do conceito acima fazer referência à interação política entre as nações dominantes e dominadas (diga-se, a prática política internacional), Cox também entende que a hegemonia se exerce a partir de formas de pensamento. Nesse sentido muito específico, no plano do "pensar teórico", as relações internacionais expressam conteúdos ideológicos que, em última instância, servem para legitimar e perpetuar certas relações de poder, que deveriam ser contestadas (COX, 2002; ASHWORTH, 2002). Mas, contestar o que exatamente, ou melhor, que conjunto de teorias? 
A impressão geral é que a ordem hegemônica ocidental gera produtos culturais (teóricos, estéticos, audiovisuais) portadores de uma visão de mundo de caráter capitalista, e, portanto, egoística. É muito curioso como, de fato, essa tendência de conceber as relações sociais de maneira atomizada, à luz das teorias da micro-economia, transparece nos axiomas das principais teorias norte-americanas das Relações Internacionais, que propõem como verdades científicas, a necessidade dos Estados aprimorarem suas capacidades relativas; pensar na busca da sobrevivência; agir estrategicamente; pensar em si, em primeiro lugar. Tais teóricos pintam um cenário cinza e pessimistas das relações internacionais e concebem, dessa forma, os fatores gerais que perpetuam, no plano do pensamento, uma sensação de insegurança e incerteza sobre o futuro (WALTZ, 2004; MEARSHEIMER, 2001).

O movimento pós-hegemônico na Teoria das Relações Internacionais aparece justamente para ajudar o processo de superação da mentalidade conceitual descrita acima, que, aliás, "congela" as possibilidades de transformação do mundo. Desse modo, em primeiro lugar, o que as teorias críticas propõem (a partir do movimento póshegemônico) é uma nova visada sobre as teorias vigentes, de tal modo que se possa apontar sua parcialidade e corrigi-la. Mas, corrigir de que modo? O propósito é simples: o que se tenta é abrir um espaço mais amplo de discussões capaz de incorporar, no plano do "pensar teórico" autores desconhecidos, tradições silenciadas, textos nãoocidentais para fazer um balanço entre visões de mundo, e daí encontrar novas possibilidades de pensamento e ação.

É preciso ressaltar que o movimento pós-hegemônico não tem como finalidade invalidar as teorias hegemônicas já existentes. A pós-hegemonia propõe a utilização, no campo de estudos, de lentes teóricas diversas, não ocidentais, por exemplo, para estudar mais a fundo as relações entre os Estados. Logo, percebe-se que o estudo das Relações Internacionais realmente ganha a sua apropriação nominativa a partir deste momento, ao propor ser um campo de estudos promotora de uma espécie de tolerância de ideias difundidas em diversas realidades culturais do globo.

Mesmo assim, resta uma pergunta: para que exatamente serve essa arqueologia do saber? Qual a razão de escavar no fundo oculto das culturas novas ideias? Porque, segundo Cox, uma ordem pós-hegemônica depende de um conteúdo normativo diferenciado, capaz de adaptar melhor a aspiração humana do tempo vigente a partir de uma base comum entre as tradições que compõe a realidade cultural e civilizatória do mundo. A pós-hegemonia requer um passo fundamental, e 
uma primeira condição seria o reconhecimento mútuo das distintas tradições de civilização. [...] Uma segunda condição para uma ordem pós hegemônica seria avançar além do ponto de reconhecimento mútuo para chegar a uma espécie de supra intersubjetividades distintas e separadas das diferentes tradições de civilização que coexistem (COX, 2000).

Não se trata apenas de um resgate, mas analisar e pontuar que o reconhecimento da tradição e cultura do outro serve como um exercício de respeito à diversidade cultural, cujo propósito não é estabelecer novas hierarquias, nem valorizar uma cultura mais do que a outra; é ter em mente que cada cultura tem sua particularidade, sua individualidade, exclusividade e que se deve respeitar essas visões de mundo, apesar de distintas uma da outra. Nesse sentido específico, caberia às Relações Internacionais, enquanto um campo de estudos que estuda a sociedade de um ponto de vista global, adequar espaços epistemológicos para um diálogo multicultural verdadeiramente amplo e democrático, voltada para a busca de um ponto comum ou, como afirma Wallerstein, um universalismo verdadeiramente universal (WALLERSTEIN, 2007, caps. 2 e 4).

Dentro desse contexto, a presente pesquisa resgata o pensamento e a doutrina de Zoroastro, sábio, legislador e poeta da Pérsia antiga. Esse movimento de resgate faz parte de uma tendência, em Relações Internacionais, de retornar ao passado em busca de alternativas, ou melhor, novas maneiras de ver e interpretar o mundo social e político. Diante dos dilemas éticos e morais vivenciados pela presente geração, os apelos em torno da renovação da ordem social e política exigem uma investigação da própria sociedade, ou melhor, é preciso buscar compreender as possibilidades de emancipação contidas nela mesma, apesar de suas construções patológicas, muitas delas elaboradas em formas de dominação.

A crença é de que em meio às ideias vitoriosas no tempo houveram doutrinas silenciadas: elas jazem parcialmente ocultas sob as edificações teórico-filosóficas vigentes. Assim, deve-se buscar, numa revisão da edificação civilizacional, possíveis etapas que ofereciam outras saídas e alternativas para a humanidade; mas, vencidas, ficaram depositadas nas camadas do tempo. O desafio, portanto, é empreender uma "arqueologia do saber" para reencontrar, nos fundamentos da civilização vigente, tendências culturais, intelectuais, religiosas, sociais, políticas e econômicas, capazes de eliminar um ou outro abuso. 
Dentre as várias contribuições e tradições espalhadas pelo mundo, é possível imaginar antigas civilizações, tais como a Pérsia, como um repositório de importantes reflexões sobre moralidade, sociedade, política e economia. Nela, encontra-se o Zoroastrismo, uma doutrina que desempenhou um importante papel no desenvolvimento de regiões consideradas como o berço de nossa civilização atual. O Zoroastrismo busca, por meio de uma metafísica, observar a natureza, os indivíduos e suas relações para sugerir um guia de ação cujo propósito é preveni-los dos males da vida existencial. Nesse espírito, essa pesquisa pretende apresentar os fundamentos ontológicos da doutrina de Zoroastro, nos seus próprios termos culturais e históricos, com a finalidade de repensar, mais tarde, e criticamente, os nossos pressupostos, assumidos, muitas vezes, como "verdades" em teorias vigentes da sociedade e das Relações Internacionais. 


\section{CRONOLOGIA}

- 600-583 a.C (aprox.) - Surgimento do profeta, filosofo e poeta, Zoroastro.

- 550-330 a.C - Império Aquemênida.

- 492-479 a.C - Persas tentam conquistar a Grécia e perdem a batalha.

- 334 a.C - O líder Macedônio Alexandre, o Grande, derrota os Aquemênida e toma o Império Persa.

- 323 a.C - Alexandre morre e consequentemente, seu império é fragmentado. Um dos seus generais funda a dinastia Selêucida.

- 230 a.C - Tribos Partas derrotam gradualmente os Selêucidas e assumem o controle da Pérsia.

- 224 - Império Sassânida emerge e inaugura a teocracia Zoroastra.

- 632 - Maomé recebe revelação do Corão e morre na Atual Arábia Saudita. Seus seguidores se lançam a conquista de territórios vizinhos.

- 633 - Árabes invadem o território Sassânida iniciam a islamização da Pérsia. O ano é conhecido como o maior genocídio histórico, pois, a Pérsia foi islamizada por meio da força física e econômica, medo de perderem suas vidas e suas famílias e pelo receio de serem punidos com altas cobranças de impostos.

- 661 - Ali, neto e genro de Maomé, são assassinados. Seguidores de Ali formam uma dissidência que sela o início do xiismo.

- 680 - Hussein, filho de Ali, é assassinado pela dinastia Umíada, dominante na região.

- 696 - O árabe se torna o idioma oficialdas terras conquistadas pelo islã.

- 750 - Com apoio das tribos persas, a dinastia Abásida derrota os Umíadas.

- 820 - A proliferação de pequenos Estados persas restringe o domínio árabe sobre a Pérsia. Surge então, o idioma farsi moderado que usa a escrita com base no alfabeto árabe.

- Século X - Início do colapso do califado islâmico, que cede espaço a diversas dinastias persas e turcas como a dos seljúcidas.

- 1220 - Exercíto Mongol sob comando de Gengis Khan, invade, arrasa e ocupa boa parte da Pérsia.

- 1227 - Gengis Khan morre. Seus filhos repartem o Império.

- 1271 - Marco Polo atravessa a Pérsia e relata horrores da destruição causada pelos mongóis. 
- 1405 - Timur, comandante turco-mongol, conquista a Pérsia, que é novamente devastada por invasores.

- 1501 - Xá Ismail reunifica a Pérsia e funda a dinastia Safávida. O islã xiita é declarado religião oficial. 


\section{CAPÍTULO 1 - O CONTEXTO HISTÓRIO}

\subsection{O MUNDO PAGÃO ANTECEDENTE A ZOROASTRO}

O período anterior a Zoroastro é caracterizado por uma sociedade denominada "indo-iraniana". A sociedade indo-iraniana viveu por volta de 1700 B.C, em grupos, dos

quais esses eram nômades e mudavam-se constantemente com o seu rebanho. $\mathrm{O}$ rebanho da vida nômade era composto por três animais de extrema importância: o cão (com a finalidade de proteger a tribo), o cavalo (como meio de transporte) e a vaca e boi (como forma de alimento). Esses animais ganharam sua importância social e também religiosa na corrente pagã indo-iraniana; e tal simbologia foi mantida na cultura zoroastriana (BOYCE, 1989, p.3)

Os indo-iranianos ocupavam as regiões do Uzbequistão, Tajiquistão, Turcomenistão, Irã, parte da Índia e por fim, o Quirguistão. Sua tradição, semelhante a do povo Mongol, mantinha o respeito ao valor da lealdade mútua e a obrigação aos seus chefes e líderes, pois acreditavam que o poder deveria estar nas mãos de grandes chefes, sendo esta prática conhecida como "feudalismo nômade". Essa forma de organização social e política eminentemente patriarcal refletia nos deuses pagãos. A vista disso, acreditavam nos "Asuras" ou "MihrYast", expressões usadas pelos pagãos para se referirem ao "deus" que é "rei de vários países e/ou impérios": uma imagem da qual possivelmente foi remetida aos chefes tribais ou aos reis vassalos como modelo de virtude e sabedoria (BOYCE, 1989, p.4)

Os indo-iranianos não tinham uma estrutura social para definir as posições sociais de seu povo, como ocorrido na Índia pós-Védica no sistema de castas (BOYCE, 1989, p.4). Entretanto, naturalmente as crianças seguiam a mesma vida profissional dos pais por intermédio de ofícios que eram ensinados desde a infância. Heródoto, por exemplo, registra o período Persa do século quinto B.C para descrevera formação das crianças persas, especialmente os meninos: aos cinco anos de idade, aprendiam a montar, a atirar e a falar a verdade - eram formados para serem nobres e guerreiros. Esta tradição sobreviveu até o século XX (BOYCE, 1989, p.6). 


\subsection{ZOROASTRO E A DIFUSÃO DA DOUTRINA}

A biografia de Zoroastro usualmente é cercada de lendas e certos mistérios. Zoroastro foi o maior profeta entre os antigos iranianos. Ele tomou seu nascimento para estabelecer o culto de Ahura Mazda, o Senhor Supremo do Universo e para cumprir a Missão Divina. Suas próprias escrituras originais, as preciosas Gathas na língua avestânea, indicam que ele era uma pessoa "intoxicada" por Deus.

O pai de Zoroastro era o venerável Porushaspo e sua mãe Dughdhvo. Zoroastro nasceu no oeste do Irã em Takht-e-Suleman, no distrito de Azerbaijão. Ele era um descendente direto na linha real da casa de Manushcihar, o antigo rei do Irã. O Profeta do Irã é conhecido por seus seguidores como Zaratustra (posse de camelos amarelos ou velhos. 'Ustra' significa camelos). Quando o Profeta do Irã nasceu, a natureza se alegrou. As árvores, rios e flores expressaram sua alegria e prazer. Os demônios estavam assustados. Assim que a criança nasceu, ele não chorou como um mortal comum. Ele riu alto. Muitos anjos e arcanjos vieram adorá-lo.

O nome de família de Zoroastro era 'Spitama', que significa 'Branco'. Zoroastro tinha dois irmãos mais velhos e dois irmãos mais novos. O nascimento de Zoroastro era milagroso. A glória de Ahura Mazda desceu do céu e entrou na casa da futura mãe do profeta. Quando ela estava grávida, os arcanjos vieram até ela e adoraram e elogiaram o nascituro.

Zoroastro casou-se três vezes e teve muitas crianças. Sua primeira esposa teve um filho e três filhas. A filha mais nova Pourucista casou-se com Jamaspa, que era o tio da terceira esposa de Zoroastro. Zoroastro teve dois filhos por sua segunda esposa. Sabemos muito pouco da vida adiantada de Zoroastro. Mesmo quando ele era um menino, ele mostrou grande sabedoria. Ele argumentou com homens sábios e censurou os hereges. Demônios e espíritos malignos tentaram matá-lo. O rei Turanian Durasrobo também tentou matar a criança, mas a vida do profeta foi salvada milagrosamente pelo Senhor todo misericordioso.

Zoroastro desenvolveu desapegação quando atingiu os dezesseis anos de idade. Os objetos do mundo perderam toda atração por ele. Ele desprezava todos os prazeres mundanos. Ele se elevou acima de todos os desejos sensuais. Ele mostrou intenso amor e compaixão por todos os seres vivos. Zoroastro deixou sua casa aos vinte e vinte e vagou de um lugar para outro. Ele liderou uma vida de pureza e justiça. Ele vagava nas 
florestas. Ele morava sozinho em cavernas e montanhas. Ele controlou sua língua e subjugou seus outros sentidos também. Ele era muito abstinente em sua dieta. Ele passou seu tempo em meditação tranquila.

Zoroastro experimentou Samadhi ou comunhão com Ahura Mazda, o Senhor Supremo do Universo, no topo do Monte Sabatão. Ele tinha visões divinas proféticas. Ele conversou diretamente com Ahura Mazda e recebeu a sabedoria do Senhor. Ele recebeu sete revelações de Ahura Mazda. Aos trinta anos, ele saiu como o Profeta de Deus. Depois de receber a luz divina da revelação, ele se tornou o renomado mensageiro de Ahura Mazda.

Vários arcanjos ajudaram Zoroastro no caminho espiritual. Os arcanjos são mensageiros divinos da mais alta ordem. Eles são os atendentes de Ahura Mazda. Eles correspondem aos Siva-Ganas - os atendentes do Senhor Siva - e a Jaya, Vijaya, Nanda, Sunanda - os atendentes de Lord Vishnu. São as divindades guardianas ou as Lokapalas do mundo. Zoroastro conversou diretamente com esses arcanjos.

Vohumanah é o arcanjo do bom pensamento. Ele também é o Senhor presidente dos animais domésticos. Ele apareceu antes de Zoroastro e o ajudou a retirar a bainha física e dirigiu sua alma para a morada suprema de Ahura Mazda. O próprio Ahura Mazda deu instruções ao Profeta e lhe concedeu sabedoria divina. Zoroastro obedecia os comandos de Ahura Mazda.

Quando Zoroastro estava descendo da morada celestial de Ahura Mazda, ele foi terrivelmente atacado pela força do mal Ahriman, o Satanás do zoroastrismo. Ahriman queria matar Zoroastro, mas os poderes espirituais de Zoroastro o salvaram. O Profeta tornou-se o mestre de todos os demônios depois de conquistar Ahriman. Ele começou a pregar novamente.

Zoroastro experimentou uma segunda visão. $\mathrm{O}$ mesmo arcanjo pediu ao profeta que cuide bem os animais e proteja-os. Então Zoroastro conversou em sua terceira visão com Asha Vahishta, o arcanjo da justiça que é o Senhor presidente dos incêndios sagrados. O arcanjo ordenou Zoroastro para proteger o fogo sagrado e todos os incêndios.

Zoroastro conversou com Khehathra Vairya, o arcanjo da boa realeza que é o Senhor presidente dos metais. O arcanjo ordenou ao Profeta cuidar dos metais. Então Zoroastro conversou com Spenta Armaith, o arcanjo de modéstia, que é o Senhor presidente da Terra. Então ele conversou com Hauravatat, o arcanjo da saúde que é o 
Senhor presidente das águas. Por fim, ele conversou com Ameretat, o arcanjo da imortalidade que preside plantas.

Zoroastro tinha um conhecimento perfeito da hierarquia celestial dos deuses através dessas visões. Zend Avesta, que é a Bíblia e a Gita dos Parsis, contém a sabedoria que o Profeta recebeu de Ahura Mazda, o Senhor Supremo. As experiências divinas de Zoroastro são semelhantes às experiências de Satyakama Jabala do Chandogya Upanishad. O Deus do Vento, o Deus do Fogo, o Deus do Sol, e Varuna ou a Deidade das Águas transmitiram a sabedoria divina a Satyakama. Arcanjo Vahishta é o Deus do fogo ou Agni dos hindus. Arcanjo Hauravatat é Varuna dos hindus.

Zoroastro peregrinou em várias cidades e vilas da Pérsia, difundindo a doutrina zoroastriana para uma sociedade que até então era pagã. Durante sua peregrinação, Zoroastro encontrou o reinado de Lohrasp onde continuou seu trabalho, divulgando a fé zoroastriana, entretanto, essa atividade incomodou vermentimente o rei Lohrasp, que questionou a fé zoroastriana e desacreditado, se fez opositor a ideologia monoteista. Sendo assim, prendeu Zoroastro como forma de punição.

Certo dia, o rei passou dificuldades com seu cavalo predileto e solicitou ajuda para salvar a vida do animal. Zoroastro, por ter vivido em uma vila rural, se dispôs a ajudar o rei nesta causa, pois detinha conhecimentos específicos. Zoroastro obteve sucesso no salvamento do animal e, com isso, o rei demonstrou-se grato e decidiu soltálo e escutar seus ideais abertamente. Em pouco tempo, não só Lohrasp e sua família haviam sido convertidos a doutrina Zoroastrina, como também grande parte de seu povo.

Mas, quem era Lohrasp Padshah (rei Lohrasp), essa figura cuja dinastia marcaria a vida de Zoroastro? Conta-se que Lohrasp era um governante gentil, nobre e piedoso de uma pequena província. Os relatos sobre Lohrasp contam que Sarosh Yazad guiou divinamente o Rei Kayaniano Kae Khushru para nomeá-lo como seu sucessor. O nome Avesta de "Lohrasp" é uma abreviatura de"Aurvat-aspa" que significa "dono de um cavalo rápido". Na tradição religiosa, Lohrasp é chamado "Mithra-naa-saheb”ou "mestre da força do pensamento". Como ele tinha enorme poder sobre sua mente e pensamentos, se acredita que ele tenha tido a capacidade de projeção astral em outro lugar de tal maneira que parecia que ele estava simultaneamente presente em dois lugares ${ }^{1}$. Por fim,orei Lohrasp é reverenciado como uma alma altamente evoluída,

\footnotetext{
${ }^{1}$ Essa é uma característica presente na vida de muitos indivíduos considerados santos. Geralmente é denominada de bicorporeidade ou bilocação. Uma das mais notáveis histórias sobre os santos da igreja
} 
espiritualmente avançada. As pessoas que estão mentalmente perturbadas, que são acossadas por pensamentos negativos ou que têm pensamentos vacilantes podem orar a ele para obter ajuda. Sua imagem individual adorna muitos de nossos lugares religiosos.

Lohrasp teve dois filhos, Gushtasp e Zarir. Por insistência de Gushtasp, Lohrasp abdicou o seu trono a seu favor. O rei Gushtasp foi o primeiro rei que se coverteu ao zoroastrismo e fez desta religião oficial da Pérsia. ${ }^{2}$ Gushtasp ficou conhecido como o rei patrono do profeta Zoroastro. Porém, a doutrina ganhou poder e projeção com Dário e Círio, que também assumiram a religião zoroastra como oficial da Pérsia e como recurso simbólico na bandeira nacional. ${ }^{3}$ Heródoto descreve Círio como o governante que fundou o império com base na generosidade em vez da violência e da tirania. Nesse sentido, é notável a influência da doutrina de Zoroastro sobre a política a tal ponto de Círio ser considerado antítese para o príncipe ideal de Maquiavel, pois um dos maiores ideais de liderança era baseado no princípio da cordialidade e respeito (HERODOTO, 2001, I, p. 136).

Há um desejo profundo e geralmente frustrado no coração de todos para agir com benevolência, em vez de egoísmo, e uma boa instância de generosidade pode inspirar dezenas mais. Assim, estabeleci um tribunal majetastoso onde todos os meus amigos mostraram respeito um ao outro e cultivou cortesia até florescer em perfeita harmonia (KAPADIA, 1905, p.17).

É possível concluir que tal ideal de liderança estabelecido por Círio foi baseado nos princípios morais e éticos de Zoroastro e na tríplice da bondade ${ }^{4}$. Estes princípios foram postos em prática no governo de Círio e o fez ficar conhecido como um dos maiores imperadores da história (KAPADIA, 1905, p.17). A prática destes princípios deixa em aberta a seguinte questão: Círio conseguiu difundir a paz e a harmonia entreos povoados com distintos grupos étnicos em seu Império? Em qual medida os princípios éticos e morais por ele utilizados podem ter validade na práxis das relações internacionais contemporâneas com o objetivo de se alcançar a paz e a harmonia entre as nações.

conta que Santo Antonio de Pádua pregava na Igreja de São Pedro Quadrívio, na cidade de Limonges, na França e que, no máximo da exposição, ficou paralisado e imóvel no púlpito. Nesse mesmo instante, foi visto em outro lugar da cidade entre frades de um convento entoando com eles hinos matinais.

${ }^{2} 600-583$ a.C

${ }^{3}$ Século 5 d.C

${ }^{4}$ Tríplice da bondade é a representação dos princípios morais zoroastrianos e consistem em bons pensamentos, boas palavras e boas condutas. 
O zoroastrismo floresceu por muitas gerações. Entretanto, em 642 A.D, o mazdaísmo foi massacrado pelo Califado árabe de Omar durante a batalha de Nehâvand. Tal momento histórico foi descrito por Thomas Moore da seguinte forma: "o orgulho do Irã se foi para sempre, extinguido com a chama nas cavernas de Mithra. Não, ela tem filhos que nunca, jamais se tornarão escravos de muçulmanos, enquanto houver luz, terra, haverá sepulturas" (KAPADIA, 1905, p.49). Aos que não aceitaram se submeter ao regime islâmico pós-invasão árabe na Pérsia, restou o ostracismo: foram buscar hospitalidade na Índia oriental e ali mesmo formaram uma comunidade que preservou a cultura originária dos persas, conhecida como Parsis. Entretanto, é um equívoco acreditar que os iranianos somente tiveram contato com a Índia após a queda do império Sassânida.

O fato é que os antepassados indianos e iranianos ficaram juntos como arianos, mesmo antes do Irã e da Índia terem surgido. Nas narrativas Shahnameh dos reis Peshdadian e Kayanian do Irã antigo, encontramos uma referência à Índia em vários lugares. Como por exemplo, uma parte do noroeste da Índia, composta nos dias modernos por Sindh e Punjab, pertencia ao império aquemênico, e reis Sasanianos como Behram V (Behram Gur) e Chosroe I (Nosherwan Adel) tiveram relações políticas com a Índia. Assim, após a queda do império Sasaniano, a Índia era a escolha natural dos zoroastrianos iranianos como uma segunda casa, longe de casa, já que os zoroastrianos iranianos estavam conscientes da tolerância dos governantes indianos e da natureza inclusiva das religiões indianas (BOYCE, 1989, p.9).

\subsection{HERANÇA DO PERÍODO INDO-IRANIANO DIFUNDIDO NO ZOROASTRISMO}

Os sacerdotes do período indo-iraniano tinham diferentes vocações, mas compartilhavam uma única formação básica, pois há elementos comuns nos rituais zoroastrianos e brâmanes, o que mostra que há uma tradição antiga que foi transmitida de geração em geração por trás deles (BOYCE, 1989, p.10). Os sacerdotes seguiam um mesmo ritual de palavras sagradas, hinos e cantos de louvor para agradar aos deuses em suas oferendas. Durante centenas de anos, os brâmanes e os zoroastrianos mantiveram essa tradição de orações e hinos, apesar de terem uma certa liberdade para compô-las novamente dentro das convenções estabelecidas. 
Existem três categorias de expressões religiosas formais conhecidas. Em primeiro lugar, a palavra "mantra" ou "manthra" significa reflexão, pensamento. Sendo assim, a palavra "mantra" é definida como "instrumento de reflexão", formulada e utilizada para se referir à meditação. $\mathrm{O}$ mantra era acompanhado nos rituais e inspirava sacerdotes a compor tais enunciados. No idioma Védico, existe a expressão "criador de mantra" que se referia à pessoa que enunciava o mantra de cór, "vinda do coração" para que seu povo lembrasse e repetisse depois dele.Há uma frase nos Gathas conhecida como: "de coração e pensamento" e esta frase mostra a verdade sobre o histórico ancestral dos indo-iranianos (BOYCE, 1989, p.11). Ou seja, em dado momento, as duas correntes hindu e zoroastra carregam a mesma origem da tradição pagã indo-iraniana.

No período Védico, o adjetivo "mantrin" significava "conhecedor dos mantras" e Zoroastro usava repetidamente a ideia de que um iraniano equivale a um "mantran" (conhecedor de mantras) dele mesmo. Em geral, parece que as expressões utilizadas por sacerdotes de ambas as correntes reveladas eram inspiradas no mais restrito sentido. De fato, tal inspiração era sustentada por uma divindade ou por uma faculdade de conhecimento adquirida pelo próprio sacerdote.

Em segundo lugar, o louvor, o discurso público de louvor ou a poesia religiosa recitada por meio da música têm as mesmas características no Avesta e na Índia, nos hinos "cânticos" do Udgatr. Em ambos, o louvor deve ser expressadoverdadeiramente e o sacerdote deve ser corretamente instruído, tanto no conhecimento religioso, quanto na arte da composição ${ }^{5}$.

O zoroastrismo e o hinduísmo também são similares no que tange aos hinos, pois ambos têm medidas próximas, caracterizadas por oito sílabas e são simples e diretos no seu conteúdo e expressão. O louvor, o discurso público de louvor ou a poesia religiosa recitada por meio da música, têm as mesmas características no Avesta e na Índia, nos hinos cânticos do Udgatr. Em ambos, o louvor deve ser expressado verdadeiramente e o sacerdote deve ser corretamente instruído tanto no conhecimento religioso, quanto na arte da composição. O zoroastrismo e o hinduísmo também são similares no que tange aos hinos, pois ambos têm medidas próximas, caracterizadas por oito sílabas e são simples e diretos no seu conteúdo e expressão (BOYCE, 1989, p.36).

\footnotetext{
${ }^{5}$ Essa tradição sobreviveu até meados do século XX, quando os filhos de sacerdotes eram educados e recebiam de forma exigente o "chamado" aos sete anos de idade.
} 
Há poesias representadas nos Gathas (as quais foram compostos por Zoroastro) e na Índia, poesias de sabedoria do Hatar $^{6}$, com versos caracterizados por onze sílabas. As poesias de Zoroastro e Hatar têm seu conteúdo predominantemente instrutivo. Tal tradição foi familiarizada pelo fatodos sacerdotes serem ensinados a dedicar anos de estudo para investigar a verdade e elucidar a natureza das coisas. Provavelmente, esta antiga categoria de poesia parece ter raízes indo-europeias cultivadas particularmente em conexão com a atividade mântica ${ }^{7}$.

\subsection{OS DEUSES PAGÃOS DO IRÃ}

O Avesta ${ }^{8}$ possui vários seres divinos que são honrados e provavelmente são originados dos panteões iranianos. Alguns deuses maiores também foram adorados pelos indianos védicos. Um grande exemplo é a deusa Mithra, a qual faz adorações a Ahura Mazda, o descrevendo como: "ele olha para tudo entre a terra e o céu"; "ele abraça/oferece refúgio com sua grandeza"; "O lugar dele é na largura da terra" (BOYCE, 1989, p.22)

É possível compreender que há uma correlação entre a vida dos deuses e a vida nômade, vivida nos grandes estepes, a partir dos relatos da deusa Mitra. A concepção monoteísta de Zoroastro sobre um Senhor supremo foi derivada das expressões indoeuropeias, descritos como "a luz que brilha"; "única luz" que também era chamada de “imortal” (BOYCE, 1989, p.23). Os iranianos também utilizam o termo "o único que distribuí’. Logo, sob uma perspectiva histórica, os termos zoroastrianos são Védicos, pois na religião védica, a asura corresponderia a ahura, utilizado no Avestapara para se referir ao "Senhor": em ambos os idiomas, o termo se refere a Deus.

\footnotetext{
${ }^{6}$ Cerimônias de sacrifício referente ao período védico. Tal cerimônia deveria ser composta por sacerdotes, que tinham como função a invocação de deuses.

7 Atividade mântica quer dizer "guiar o humano sobre seu futuro com profecia e adivinhação".

${ }^{8} \mathrm{O}$ Avesta é o livro sagrado do zoroastrismo contendo sua cosmogonia, lei e liturgia, os ensinamentos do profeta Zoroastro. Os volumes manuscritos do original destruídos quando Alexandre, o Grande, conquistou a Pérsia. O presente Avesta foi montado a partir dos restos encontrados e decorados pelos sacerdotes, o Avesta também foi titulado pelos reis Sāsānianidos. OAvesta está em cinco partes. Seu núcleo religioso é uma coleção de canções ou hinos, os Gāthās, que se pensava ser as principais palavras de Zoroastro. Eles formam uma seção do meio da principal parte litúrgica do cânone, o Yasna, que contém o rito da preparação e do sacrifício de haoma. O Visp-rat é uma escritura litúrgica menor, contendo homenagens a vários líderes espirituais zoroastrianos. A Vendidad, ou Vidēvdāt, é a fonte principal da lei zoroastrista, tanto ritual como civil. Também dá conta da criação e do primeiro homem, Yima. Os Yashts são 21 hinos, ricos em mitos, sobrevários yazatas (anjos) e heróis antigos. O KhūrdaAvesta (ou Little Avesta) é um grupo de textos menores, hinos e orações para ocasiões específicas.
} 


\section{CAPÍTULO 2 - A DOUTRINA}

\subsection{A ÉTICA ZOROASTRIANA}

A ética zoroastriana é simples: o que contribui para a futura vitória do bem sobre o malé retribuire ser aconselhado, acima de toda devoção voluntáriaou honestidade, veracidade, generosidade e moderação; $O$ que deve ser evitado e punido, especificamente, é o torto, o desvio, o engano ea avareza ou ganância. Esses valores básicos são constantemente enfatizados e detalhados $[95 ; 96 ; 73 ; 131 ; 135]$. Os valores mais importantes são a pobreza e a justiça: tratar todos com equidade, sem distinguir as classes sociais, sejam estas altas ou baixas. Outro princípio relevante é o da moderação, não se deve haver o excesso de trabalho, nem a falta de ação, este elemento é primordial. O que contrapõe estes princípios são a ganância, a luxúria, o desejo, o ódio, a inveja, etc. Os termos mais genéricos são frãrõneabãrõn, que significam, aproximadamente, "moralmente bom e mal". Ser sincero e honesto em particular, incluia abstinência da calúnia (SKJAERVO, 2011, p.33).

Testamento de Darious: Túmulo de Darious em Naqsh-e Rostam Rei Darious anuncia: Pela grandeza de Ahura Mazda, sou tão favorável ao que é reto / verdadeiro, não o que é tortuoso. Não é meu desejo que um homem pobre seja injustiçado por causa dos poderosos, nem que os poderosos sejam injustiçados por causa dos pobres. O que é reto, esse é o meu desejo. Eu não sou um amigo daquele que mente.

$\mathrm{Eu}$ sou de acordo com sua conquista que o homem se exerce. Eu puno de acordo e na mesma proporção da sua maldade, daqueleque faz o mal. Não é meu desejo que um homem seja mau, nem que um homem faça o mal não deve ser punido. Eu não acredito no que um homem diz contra contra outro homem até ouvir o testemunho de ambos. Ficosatisfeito em estar ciente sobre o que um homem fez ou provocou de acordo com suas capacidades. É o que eu realmente desejo e o que me agrada. Minha compreensão e intenção são de tal maneira que você vê ou ouve sobre o que eu fiz, tanto em casa como no exterior. Esta é a minha agilidade no pensamento e na compreensão. (SKJAERVO, 2007, p.191). 


\subsection{O SIGNIFICADO DO PRINCÍPIO DOS BONS PENSAMENTOS}

Os Gathas $^{9}$ são proclamados por um manthran autodeclarado $(3.50 .5,6)$; é alguém cujas enuncias poéticas representam uma profunda compreensão conceitual e existencial. A base do manthrané o homem da raiz verbal, para "pensar" (como no "processo mental"). Alguns traduzem a palavra manthran como "profeta", mas pertence mais facilmente, na designação indo-iraniana, a uma cristalização verbal de uma visão conceitual. A noção de clareza e foco do pensamento tem como princípio central a filtração do pensamento através dos Gathas em muitas formas. As palavras de cognato incluem manah, que significa "pensamento" (em vez de "intenção" ou "propósito", como às vezes é traduzido); Manyu significa "inspiração" ou "estímulo mental/mentalidade" no nível poético e no de escolha,"espírito", no mesmo sentido de algum tipo de entidade mítica no mundo de menog. Mazda é um substantivo cognato, composto por homem $+d \tilde{a}$, e é mais exatamente traduzido como "aquele que mantém a trilha mental" ou "aquele que é sábio/experiente". O outro epíteto que muitas vezes aparece ao lado de mazda, no Gathas, é ahura. Uma etimologia para ahura é um verbo que significa "engenheiro". A tradução mais precisa do nome de duas partes Ahura Mazda é "Senhor Sábio" ou "Senhor Sensato".

A boa criação de Mazda inclui o mundo conceitual (manahiia) do pensamento e corpóreo (gaetha) ou "bone"(astvant). Essas duas dimensões não estão em conflito, mas são distintas no primeiro, só podem ser percebidas pelo pensamento ou pela inspiração, enquanto a visão dos seres físicos é apreendida através dos sentidos encarnados, particularmente da visão e da audição. Acredita-se que as palavras pronunciadas (1.31.19) ressoam entre as esferas. Ou seja, o pensamento é responsável pelas palavras que são ditas e pelas ações humanas. Ter bons pensamentos é seguir a tríade dos princípios éticos zoroastrianos, que seria ter boas palavras seguido de boas condutas (ROSE, 2011, p.12)

A palavra, a ação, a audição e a visão não são todas e não desempenham um papel primordial na relação entre deuses e homens. A palavra e a ação são apenas a

\footnotetext{
${ }^{9}$ Os Gathas são canções numinosas criadas por manthras, que também são descritas como vitva, "aquele que sabe". São, também, poesias métricas com conteúdo instrutivo sobre a natureza das coisas, que assumem um conhecimento subjacente por parte daqueles que as ouvem.
} 
extensão, a manifestação material da força fundamental. Uma característica adicional do homem é quando ele sacrifica que ele deixa esse estado e entra no "estado de pensamento" - típico dos deuses - o que o torna digno e capaz de obter contato com os deuses. É por isso que este estado de pensamento é chamado como o primeiro, primordial e importante. Pois, provoca agrandeza dos deuses e constitui a natureza humana. Vohu Manah, que é o pensamento bom e divino, garante a conexão entre o comportamento ritual e o princípio da estrutura cósmica ordenada. É a faculdade que permite ao homem reconhecer essa estrutura, compreendê-la e reproduzir em seu comportamento, numa percepção que o coloca em harmonia com o deus e, de alguma forma, no seu nível: "pensar estrutura ordenada" é o ato arquetípico de Ahura Mazda que o caracteriza como bom sacrificador (KELLENS, 1990, p.107).

\section{CAPÍTULO 3 - AS RELAÇÕES INTERNACIONAIS}

\subsection{ZOROASTRISMO NA GEOPOLÍTICA DO MUNDO ATUAL}

Após a invasão árabe na Pérsia em 633, houve uma imposição militar e econômica do islã a população persa e dessa forma, o zoroastrismo foi silenciado e o islamismo foi empoderado se tornando popular entre os persas e então a partir do século IX, se tornam a maioria religiosa. Em contrapeso, os árabes absorverem vários elementos culturais persas, como por exemplo o sistema do governo sassânida, seu padrão fiscal eficiente e seu moderno modelo de gabinete de vizires (ministros). $\mathrm{Na}$ mesma época, muitos artistas, cientistas, arquitetos e engenheiros persas que foram convertidos ao islã compuseram a conhecida era de ouro islâmica. Apesar do enriquecimento mútuo entre as culturas, a invasão árabe não deixou de esquecida e continuou sendo palco de tensões entre persas e árabes. Houve vários levantes contra os árabes como forma de protesto de não aceitação a perda do poder territorial e a perda da identidade cultural da nação. Assassinatos contra governantes e atentados foram cometidos. Os persas sentiam-se injuriados por serem obrigados a viver sob o jugo de um povo que sempre enxergaram com desconfiança e desprezo. A hostilidade se agravava com o fato de muitos persas sofrerem discriminação, mesmo após se converterem ao islã. Esse ressentimento fomentou a aliança entre os iranianos a outros 
muçulmanos não árabes, como os curdos e turcos, contra o poderoso Califado Úmida, fundado por oligarcas da Meca instalados em Damasco, em 750 (ADGHIRNI, 2014, p.133).

Há estudos históricos que se utilizaram de fontes árabes para ilustrar sua teoria de que, ao contrário do que alegam alguns historiadores, os iranianos lutaram, na realidade, contra os invasores árabes indicando assim o desdém dos persas pela influência e cultura árabe. Esta visão também sustenta que, uma vez conquistados, politicamente, os persas passaram a resistir aos árabes culturalmente, mantendo, por exemplo, o idioma e a cultura Persa. Inclusive, durante o século VII após a invasão árabe na Pérsia Sassânida, os zoroastristas passaram a ser perseguidos pelos muçulmanos no poder e, por conseguinte, se refugiaram na Índia, na região de Bombaim. Ali eles passaram a ser conhecidos como "parsis" e continuaram a praticar o Zoroastrismo (KAPADIA, 1905, p.18).

Em 1979, houve o ressurgimento do islã na terra ariana, dado após a queda do governo monárquico do Xá Reza Pahlevi e o com surgimento da revolução islâmica. O governo islâmico, liderado pelo líder religioso Aiatolá Khomeini, impôs o islã de forma autoritária para a população iraniana, visando manter a dominância teocrática no poder. Entretanto, ainda assim, é possível constar uma resistência à imposição islâmica e uma difusão da cultura persa e da crença zoroastriana no Irã e na região mesopotâmica dada pelos povos curdos e yazidis.

É impossível negar as fortes influências que a invasão árabe na Pérsia trouxe para o atual cenário geopolítico. Tal contexto envolve a participação de inúmeros atores. No Irã, os zoroastristas sofreram um desrespeito vindo do governo do Aiatolá Khomeini em 1980, desde a conquista do governo. Impuseram uma medida de retirada da imagem de Zoroastro dos templos de fogo zoroastristas no Irã e, em seu lugar, foi posto a imagem do Khomeini e, somente após alguns meses, foi permitido retomar a imagem de Zoroastro que, no entanto, somente poderia ser posta ao lado do novo líder religioso islâmico iraniano.

Em novembro de 2005, o aiatolá Ahmed Jannati, presidente do Conselho dos Guardiões da Constituição, realizou um discurso de ódio desprezando os zoroastrianos e outras minorias religiosas como "animais pecadores que percorrem a Terra e se envolvem em corrupção". Durante a conferência, o representante parlamentar solitário dos zoroastrianos protestou contra e foi levado diante de um tribunal revolucionário. 
Ali, os mulás o ameaçaram com a pena de execução e lhe pouparam a vida com uma advertência para nunca mais desafiar as declarações dos líderes religiosos islâmicos. Por conseguinte, a comunidade zoroastrista sentiu-se acuada e recusaram-se a reeleger o representante parlamentar zoroastriano.

Nos últimos dois anos, muitos iranianos muçulmanos começaram a rejeitar publicamente os modos intolerantes da teocracia xiita, adotando símbolos e festivais do zoroastrismo. Essas ações são denunciadas como causadoras de "dano e corrupção" por aiatolás, a exemplo Khamenei e Jannati. Além dessas problemáticas, o cemitério zoroastriano fora de Teerã agora enfrenta outro desafio: o município planeja estabelecer uma rodovia que o cruzará. Algumas escolas e centros de devoção em outras fortalezas zoroastristas, como Yazd e Kerman, também foram notificadas da anexação pendente, que, inevitavelmente, pode causar danos aos patrimônios da comunidade. As reuniões comunais zoroastristas são monitoradas, rotineiramente, por autoridades muçulmanas fundamentalistas iranianas que julgam o zoroastrismo uma "ameaça a segurança nacional e subverte a revolução islâmica".

As proteções oferecidas pela constituição da República Islâmica do Irã são inexistentesna prática. Não surpreendentemente, o regime diário de discriminação faz com que os zoroastrianos se sintam totalmente indesejáveis em sua pátria iraniana: somente 35.000, de um total de 90.000 zoroastrianos, permaneceram no país. Entretanto, aproximadamente 74 milhões de cidadãos se identificam facilmente como zoroastrianos, mas, com medo da perseguição do governo islâmico, não se assumem como praticantes da religião.

Em fevereiro de 2017, por exemplo, a Associação dos Zoroastristas da Província de Yazd anunciou uma festa pública, conhecida como Sadeh para os visitantes e turistas da região. Porém, o líder da Oração das sextas-feiras, Taft Abu al-GhassemGhafoori, advertiu, com uma teoria da conspiração, que "o sionismo [Israel] e o imperialismo mundial [Estadunidense]" poderiam se aproveitar da chegada dos turistas a cidade para infiltrar-se e realizar atividades "antirrevolucionárias". Ele também pediu às autoridades locais para estarem vigilantes. O Conselho Supremo de Segurança Nacional pronunciou-se contra a festa Sadeh, alegando que este evento tem como objetivo "destruir o espírito de harmonia e cooperação entre as religiões, raças e grupos étnicos santos". Abu al-GhassemGhafoori pediu ao Conselho Supremo de Segurança Nacional que agisse de acordo com a lei e exigiu que as decisões do Conselho fossem tomadas 
com o propósito de deter "o comportamento antiético e ilegal" referindo-se ao evento zoroastriano.

Ainda sob esse cenário geopolítico, é possível mencionar o caso dos Curdos. A religião original dos curdos é o Iazidismo, a qual é muito influenciada pelas crenças judaica, zoroastriana, cristã e islâmica. Todavia, há diferenças significativas entre o Iazidismo e o Zoroastrismo, como a crença na reencarnação. A maioria dos iazidis vive no Curdistão iraquiano, nas vizinhanças de Moçul e Sinjar. O Iarsanismo é praticado no oeste do Irã, principalmente nos arredores de Kermanshah. Entretanto, atualmente a maioria dos curdos é oficialmente muçulmana, pertencendo à escola Shafi'i do Islamismo sunita.

Práticas sufistas estão também disseminadas entre os curdos. Há também uma minoria curda que é xiita, vivendo principalmente nas províncias iranianas de Ilam e Kermanshah e no leste do Iraque (curdos feyli). Os alevitas são outra minoria religiosa entre os curdos, encontrados principalmente na Turquia. Os curdos têm como cultura própria "abraçar o Islã suavemente", o que significa que sua fé tende a não ser tão assertiva quanto em outras áreas. Uma consequência disso, por exemplo, são as grandes liberdades que gozam as mulheres curdas; elas vestem hijab coloridos, deixando a mostra parte dos cabelos, deste modo, seus hijabs são menos restritivos, elas não se vestem com vestidos pretos, como o xador iraniano.

É perceptível que a cultura curda descende da cultura persa zoroastrista, entretanto, na realidade vigente, o islamismo se sobrepõe a origem cultural dos curdos. Em fevereiro de 2017, clérigo islâmico do Grupo islâmico do Curdistão (KIG) declarou em uma entrevista à $\mathrm{BBC}$ que os curdos que abandonarem o Islã para se converter ao zoroastrismo devem ser assassinados; ou em suas palavras seriam "Executados".

O clérigo estendeu sua mão de misericórdia, permitindo que esses conversos em até três dias se arrependam de sua decisão, mas, ainda assim, depois disso seriam executados. Em uma ironia quase brutal, MullaHassib de Sulaimani, disse que os princípios religiosos islâmicos permitem tais execuções, e acrescenta em sua fala que a prática do ISIS de matar apóstatas é parcialmente correta, todavia, critica a organização terrorista pela divulgação da religião Islâmica por meio da "violência. Há então, uma intolerância e perseguição aos curdos que desejam retornar às suas raízes culturais e doutrinárias, inclusive, são apoiadas as práticas terroristas do Estado Islâmico a fim de silenciar o movimento zoroastrista. 
No que se refere aos termos de reconhecimento, o zoroastrismo é reconhecido como uma crença religiosa conforme a Lei $n^{\circ} 5$ de Proteção dos Componentes do Curdistão iraquiano desde 2015, que é nova e positiva, contudo, ainda não foi permitido legalmente um templo zoroastrista. É constatado também que há perseguições da comunidade islâmica contra os zoroastristas no Iraque e, por esta causa, o povo iraquiano como um todo, sente um temor para assumir a conversão pública da doutrina zoroastrista. A prática da fé é realizada de forma oculta, consequentemente, não se torna possível enumerar os zoroastristas na região do Iraque. Apesar de toda dificuldade encontrada, o zoroastrismo encontra cada dia mais adeptos ao movimento e esse fortalecimento da doutrina zoroastrista se deve a má associação que a população mediterrânea tem tido com a conduta fanática terrorista do Estado Islâmico; a busca pela liberdade religiosa; princípios da doutrina como o respeito e zelo ao meio ambiente, respeito ao gênero feminino (a mulher ganha voz e espaço na prática da doutrina zoroastriana); princípio da verdade (exemplo: valorização do amor verdadeiro e não pelo amor comprado, dado pelo dote, como é na prática islâmica); Moral e ética, princípios puros que não abrem espaço para interpretações fundamentalistas e radicais como o islamismo.

O Estado islâmico (ISIS) tem como um de seus atos políticos a destruição de monumentos históricos milenários referentes à Pérsia Sassânida zoroastrista, todavia, tal ato, além de ser repudiado pelo povo iraquiano, ainda ganhou mais visibilidade e valorização das raízes culturais e, como resultado disso, um garoto de 17 anos, recriou os monumentos históricos visando impedir o silenciamento histórico cultural Persa. O ISIS também tem como ato de perseguição o massacre contra a comunidade yazidi e sequestro de moças yazidis, que são reféns como escravas sexuais e estupradas pelos integrantes do grupo do Estado islâmico. O povo yazidi é discriminado em sua religião, o iazidismo, por terem influências religiosas e culturais zoroastristas. Os Yazidis são vistos como "adoradores do diabo" pela comunidade islâmica iraquiana.

É notório que a invasão árabe trouxe uma série de consequências geopolíticas para a região do Oriente Médio e toda a questão de rivalidade entre árabes e persas se deve a uma imposição autoritária do islã contra estes povos que tem suas raízes zoroastristas e não se identificam com a cultura árabe e nem islâmica. Esse movimento 
islâmico busca, a todo esforço, silenciar a cultura persa zoroastrista por meio de práticas como:impedir a realização de eventos zoroastristas, o desrespeito com o espaço religioso/cultural, o não reconhecimento da religião, a perseguição sob pena de morte ou perseguição governamental/ legal com a desconsideração dos direitos civis, a destruição de monumentos históricos, o terrorismo feito às mulheres yazidis ${ }^{10}$ fazendo-as reféns e escravas sexuais (The New York Times, 2016). Estes fatos são ignorados na agenda internacional e, enquanto isso, há um grande incremento no fluxo de refugiados que sentem dificuldades para obter legalidade nos países ocidentais, porque estes mantém uma visão xenofóbica e estereotipada para com estes povos. Por estas razões, torna-se evidente a relevância de se estudar o Zoroastrismo e as consequências pós-invasão árabe na Pérsia, essa rivalidade não deve ser desmerecida e desconhecida, pois é de direito de todo cidadão a autodeterminação dos povos e a vivência em paz e com dignidade, livre de perseguição étnica, cultural e religiosa.

Desenvolver relações amistosas entre as nações, baseadas no respeito ao princípio de igualdade de direitos e de autodeterminação dos povos, e tomar outras medidas apropriadas ao fortalecimento da paz universal. Conseguir uma cooperação internacional para resolver os problemas internacionais de caráter econômico, social, cultural ou humanitário, e para promover e estimular o respeito aos direitos humanos e às liberdades fundamentais para todos, sem distinção de raça, sexo, língua ou religião. (BRASIL. Decreto $n^{\circ} 19841$, de 22 de outubro de 1945).

\subsection{O ZOROASTRISMO E A TEORIA DAS RELAÇÕES INTERNACIONAIS}

A pertinência dessa pesquisa e sua relação com a teoria estão associadas aos desdobramentos mais recentes da política internacional e da discussão acadêmica das Relações Internacionais. As mudanças ocorridas no sistema internacional com o fim da guerra fria alimentaram esperanças de um mundo mais integrado, pacífico e próspero. A globalização da economia, o avanço da tecnologia e a adoção das instituições

\footnotetext{
${ }^{10} \mathrm{O}$ iazidismo não é um ramo religioso, entretanto, expõe as influências de muitas religiões do Médio Oriente. O substancialda cosmologia iazidis tem origem iraniana e pré-zoroastriana, ademais integra elementos de antigos cultos da natureza, advindos de influências cristãs e zoroastristas.
} 
multilaterais não têm sido suficientes para difundir um crescimento econômico mais justo, incorporar sociedades mais pobres ao mercado mundial, diminuir as desigualdades sociais na política global, conforme alguns analistas haviam previsto anteriormente. As promessas consoladoras de progresso econômico e tecnológico para um mundo melhor têm sido desacreditadas pelo ressurgimento de conflitos permeados por segmentações culturais, étnicas e religiosas (Cf. ABRI-ISA, 2009).

O quadro mundial caracteriza-se por um paradoxo. Ele consiste no fato de que enquanto os meios de comunicação se desenvolvem e se tornam mais capazes de transmitir os problemas e as necessidades mundiais, e enquanto melhora a educação que faculta as pessoas pensarem racionalmente sobre a evitabilidade do conflito e a necessidade da supressão das necessidades, há evidências de que apenas o aumento da inteligência e o progresso dos meios de comunicação não garantem o desenvolvimento nem ações de política externa positivas. Niebhur (2001: p. 85) entende que a resolução deste paradoxo depende de uma discussão que coloque em pauta o problema ético e moral das relações internacionais, o que equivale a dizer, em termos práticos, que a capacidade das nações de conceberem um significado positivo para a política externa está em conformidade com a sua percepção sobre as necessidades das outras pessoas uma percepção moral, sensível do outro. Para alcançar a visão do outro, ou melhor, a alteridade nas práticas internacionais, é preciso que as Relações Internacionais, enquanto uma disciplina acadêmica, encontre formas de equacionar diferenças, pesquise pontos de convergência e reconhecimento mútuo para que se possa criar uma espécie de supra-intersubjetividade, isto é, uma ponte entre subjetividades distintas e separadas das diferentes tradições que coexistem no mundo (Cf. COX In: ROSENAU; CZEMPIEL, 2000: p. 196).

Para o surgimento de uma ordem internacional que satisfaça anseios éticos e morais, equacionando diferenças, é preciso buscar novas maneiras de se pensar e agir. A busca inicia com o esforço de compreender outros pontos de vista, justamente aqueles pontos de vista que parecem desafiar mais claramente as formas de percepção e atuação vigentes na política internacional, as "perspectivas hegemônicas”. Razão primordial para revisitar o pensamento de Zoroastro. A tradição persa ou zoroastriana corresponde a uma maneira muito diversa de se pensar a realidade e a política, uma maneira nãoocidental, e que, ao mesmo tempo, atende a alguns anseios da mente ocidental: busca por sustentabilidade; harmonia individual e coletiva; bem-estar físico integrado a um 
senso de espiritualidade. Nesse sentido, Zoroastro pode ser uma porta de entrada para acessar alternativas de pensamento e ação.

"Vivemos uma era de mudança estrutural"; com essa afirmativa, Robert Cox inicia o texto intitulado "Rumo a uma conceituação pós-hegemônica da ordem mundial", publicado em 1992 (no Brasil, publicado no ano 2000). A assertiva de Cox procurava indicar que qualquer problematização da política global deveria pressupor a existência de estruturas básicas, a partir das quais tipos significativos de entidades estariam envolvidos em formas de relação. A questão, porém, não é tão simples. Kenneth Waltz, por exemplo, em Teoria das Relações Internacionais, havia procedido justamente dessa maneira ao conceber um modelo estrutural para, em seguida, pensar as forças que determinam a interação de entidades políticas e sociais, os estados (Cf. WALTZ, 2002). Sob esse aspecto, a proposta de Robert Cox é diferenciada; apesar de convidar o estudante a investigar as estruturas por detrás da ação, ele dirá que toda conceituação sobre o mundo partirá de certezas ontológicas. Quer dizer que os termos de investigação utilizados para investigar o mundo, ou melhor, os termos empregados para definir uma estrutura social subjacente à ação sociológica - como equilíbrio de poder, sistema, estados, ordem mundial - carregará consigo graves implicações. Por exemplo: ao usar o termo política global, Cox acreditava que o investigador poderia privilegiar atores sociais impossíveis de serem apreendidos por intermédio de um conceito como política internacional, que tem, como ponto de partida, uma ontologia: a política internacional é uma relação entre estados, o que é problemático e simplificador, pois não privilegia, por exemplo, as pessoas ou os valores morais que orientam as sociedades num certo período de tempo (Cf. COX In: ROSENAU; CZEMPIEL, 2000: 184).

A verdade é que no princípio de qualquer investigação sobre as estruturas sociais está a ontologia; ponto de partida ontológico que está aberto ao questionamento. Mas, de onde decorrem as ontologias? Naturalmente, são escolhas e as escolhas ontológicas decorrem do investigador; elas advêm da sua experiência histórica, da sua formação cultural, intelectual, moral e religiosa (Cf. SMITH, 1996: pp. 1-44). Se a ontologia é o ponto de partida da investigação, todo aquele que estuda as teorias das 
Relações Internacionais - teorias que identificam e explicam as forças que compõem estruturas sociais e políticas em escala global -, deveriam se perguntar, antes de tudo, sobre quais são as estruturas ontológicas implícitas de pensamento e prática na narrativa estudada. O ponto é exatamente esse: em toda teoria não há apenas a explicação de uma estrutura "objetiva" do mundo; na verdade, a explicação de uma estrutura "lá fora" parte de uma estrutura ontológica "implícita" de pensamento e prática, que nasce e aflora no espírito do escritor (Cf., por exemplo, ASHLEY, 1996: pp. 240-53).

O ponto é que tais estruturas "implícitas" de pensamento e prática, que podem ser denominadas por "estatutos ontológicos" constituem parte do mundo que vemos e atuamos; e elas persistem, às vezes, centenas de anos como "estoques de conhecimento", ou melhor, como mananciais de "verdades" que são utilizados para julgar o certo e errado, para orientar o comportamento, para criar uma base de discurso social e intelectual, para ajudar a conceber práticas e formas de interação com a natureza. Há um ponto no tempo, porém, em que elas se mostram problemáticas ou insuficientes para responder aos anseios da sociedade (Cf. COX In: ROSENAU; CZEMPIEL, 2000 e WENDT, 1992). É quando chega a hora de empreender revisões ontológicas.

Em momentos conturbados, de crise social ou colapso ético-religioso, é preciso investigar os estatutos ontológicos das teorias, das explicações ou discursos intelectuais vigentes na sociedade, de tal modo que se possam encontrar as prováveis falhas; localizar as limitações que as têm tornado incapazes de apontar práticas positivas, capazes de aplacar a dúvida, o ceticismo, a desordem ou a perda de rumo existencial (Cf. DEVETAK, 2005). Na atualidade esse problema tem voltado com insistência no mundo das ciências sociais (Cf. HIRSCHMAN, 1986; HEILBRONER e MILBERG, 1995; CANÇADO TRINDADE, 2002). Nas Relações Internacionais, a principal linha de explicação para um certo desencanto com a disciplina tem sido o argumento de que essa ciência é de pouca ajuda para evitar os conflitos no Oriente Médio e em outras partes do mundo. O relativo fracasso das teorias universalistas em prevenir as guerras e prever crises e transformações tão profundas como o fim da guerra fria contribuiu para o enfraquecimento das tradições teóricas mais exuberantes como a norte-americana. Mesmo que essa vertente, em virtude de sua consistência epistemológica, permaneça sendo ensinada e reproduzida nos cursos de graduação e pós-graduação, despertou-se o entendimento de que novos caminhos precisam ser explorados, incluindo as trilhas que se estendam pelo passado.A tarefa que as correntes pós-modernistas das Relações 
Internacionais têm proposto é justamente a de voltar ao passado com o intuito de reencontrar pontos de partida, de rever os projetos vencidos e não explorados, de resgatar as doutrinas silenciadas e esquecidas no tempo entre lutas sociais: trata-se de uma "arqueologia do saber". Afinal, seriam os projetos perdidos e as doutrinas silenciadas boas alternativas? A pergunta justifica a pesquisa que se permite empreender uma revisão das ontologias convencionais.

Nesses termos, o presente trabalho propõe o resgate do Zoroastrismo, uma doutrina fundada na antiga Pérsia. O Zoroastrismo é uma doutrina monoteísta, fundada por Zoroastro, ou Zaratustra, profeta, poeta e legislador que viveu e ensinou na mesma época de Sólon e Tales, circa 558 a.C. (Cf. IQBAL, 2001: pp. 4-5). Desde sua fundação até o ano de 549 a.C., o Zoroastrismo se difundiu pela região que hoje compreende o Irã, o Afeganistão, o oeste do Paquistão, o sul do Turcomenistão e uma pequena área do Azerbeijão. Após um período de expansão e consolidação, o Zoroastrismo viveu um processo de retração quando a Pérsia foi invadida por Alexandre, o Grande, no ano de 330 a.C. Durante a conquista de Alexandre, boa parte da classe sacerdotal zoroastriana foi dizimada e Persépolis, a antiga capital do império persa, foi incendiada. O incêndio fez desaparecer os textos doutrinários que estavam conservados na biblioteca da cidade. Apesar do trágico evento, o Zoroastrismo sobreviveu à conquista de Alexandre e foi restaurado por volta de 224 a.C, tornando-se, lentamente, a religião das massas e sendo praticado, até o século VII d.C., por pessoas que habitavam um território que hoje compreenderia boa parte do Oriente Médio até as fronteiras da China. A culminância de sua nova expansão ocorre concomitante com a conquista árabe, quando a Pérsia se converte ao Islã. Nesse contexto, os zoroastrianos passam a ser considerados minoria e sofrem pesados tributos e pressões sociais, com o intuito de forçá-los à conversão. Aos poucos, o Zoroastrismo é silenciado e vencido pelo Islã, apesar de haver sido preservado em comunidades de zoroastrianos refugiados na Índia, os Parsis (Cf. DUCHESNE-GUILLEMIN, 1962; WIESEHÖFER, J., 1996; SKJAERVO, 2005: pp. 1$5 ; 10-12)$.

A doutrina de Zoroastro está contida no Avesta, uma forma compilada de diversos hinos: Yasna, Yasht, Videvdad e HâdôkhtNask. Os hinos propõem uma ética prática e uma leitura muito particular sobre a constituição da realidade. A ética prática zoroastriana é constituída por duas dimensões: ideias e ações. A vida ética de um indivíduo inicia com o reconhecimento das virtudes elementares, expostas na tríplice da bondade. Do ponto de vista ideacional, todo aquele que deseja ter uma vida ética precisa 
conceber ou aprender a formular bons pensamentos, boas palavras e boas condutas: são regras de ouro, que antecedem a ação (Cf. ZOROASTRO, Yasna4In: SKJAERVO, 2007, p. 3). Quando o indivíduo põe em prática a tríplice da bondade e transforma as regras em ações efetivas, elas se transformam em moralidade, ou melhor, em virtude prática. Pensar bem, falar bem e agir bem, na prática, faz o indivíduo ser justo, reto, cooperativo, verdadeiro e bom e assim ele se integra com a ordem cósmica e natural do mundo (Cf. ZOROASTRO, Yasna 10 In: SKJAERVO, 2007, p. 9).

Zoroastro entende que os seres humanos são livres, porém, são recompensados ou punidos, em vida, conforme as escolhas que fazem. Deliberar bem, portanto, é essencial para uma vida plena, satisfeita e feliz. Ao praticar as virtudes, isto é, ao agir moralmente, o ser humano adquire uma prática de viver; ao aprender a respeitar as regras ou os limites imanentes da vida, o indivíduo se integra ao meio natural e social, sendo capaz de criar ao seu redor uma ordem positiva (asha). Todos são responsáveis por suas deliberações éticas, e a ordem humana e social não passa do conjunto ou soma de boas deliberações individuais, pois são as boas deliberações que aproximam ou integram os indivíduos a uma ordem natural, constitutiva e presente em todas as coisas, essencialmente marcada pelo bem (Cf. SKJAERVO, 2005: p. 13-14).

É possível sintetizar a doutrina de Zoroastro em seis princípios elementares, que são os seguintes: (i) os indivíduos são livres, mas são recompensados ou punidos em vida conforme a sua conduta. Tudo o que se faz tem uma consequência para o bem ou para o mal; (ii)os seguidores da fé devem ser bondosos e amorosos; (iii) deve-se agir como gostaríamos que agissem conosco; (iv) aprender a viver moralmente é integrar-se à ordem natural do cosmos; a vida ética aumenta as chances de bem-estar individual e bem-estar coletivo; (v) os indivíduos devem encontrar o seu lugar no planeta de forma harmoniosa, buscando o equilíbrio com o meio natural e social, respeitando e protegendo a terra, a água, o ar, o fogo e a comunidade; (vi) cobrar juros aos integrantes da religião é considerado o pior dos pecados; reprova-se o acúmulo de riquezas (Cf. ZOROASTRO, Yasna 0-72; Yasht 1-19; Videvdad 1-22 In: SKJAERVO, 2007, pp. 1127).

Tais princípios constituem, diríamos, uma leitura do "real", que apesar de vencida por outras visões de mundo e esquecida na história, parece contrastar com as leituras ocidentais sobre a constituição da realidade; leituras, aliás, que servem de ponto de apoio para as reflexões sobre relações internacionais. É curioso comparar os seis princípios zoroastrianos com os seis princípios de Morgenthau, por exemplo. A 
doutrina de Morgenthau, considerada como ponto de partida para os estudos teóricos em relações internacionais é, por excelência, uma doutrina aristotélico-mecanicista. Ela propõe uma leitura do mundo centrada em leis objetivas que decorrem da natureza humana. Para compreender a sociedade e a política seria preciso entender a natureza humana em que as leis da política e da sociedade têm as sua raízes (Cf. MORGENTHAU, p. 5).

Partindo de uma ideia de sujeito e de uma natureza humana atemporal, Morgenthau irá observar as relações internacionais como a composição de unidades autônomas imbuídas de desejos, isto é, de uma perpétua busca por poder. Nessa circunstância, a vida é incerta e as relações entre os povos não passa de um tenso e conturbado jogo de interesses, em que pese à vontade do mais forte. Em tal condição, não há muito espaço para a confiança, a moralidade é fraca e o direito internacional ineficiente, pois os estados dependem muito mais da prudência, ou melhor, de ações isoladas que os permitam satisfazer as suas necessidades. Em tais circunstâncias, a necessidade é a maior virtude (Cf. HASLAM, 2006).

Os princípios de Morgenthau estão sintetizados em seis: i) a política e a sociedade possuem leis objetivas que deitam raízes na natureza humana; ii) o conceito de interesse definido em termos de poder é o que situa o realismo e o estadista nas relações internacionais; iii) o conceito de interesse definido em termos de poder é uma categoria objetiva e válida universalmente; iv) há uma tensão inevitável entre o mandamento moral e as exigências de uma ação política de êxito; v) é problemático identificar as aspirações morais de uma determinada nação com as leis morais que governam o universo; vi) o realismo se diferencia de outras escolas de pensamento, sobretudo daqueles que ponderam a dimensão ética e moral (Cf. MORGENTHAU, 2004, pp 4-28).

Como é possível notar, tais princípios estão constituídos por estruturas ontológicas rígidas e estritamente ocidentais. Em primeiro lugar, elas remetem a Tucídides (2001, p. 351) e à Grécia antiga; em segundo lugar, pensam a natureza humana em termos atemporais, uma natureza que é e sempre será constituída pelo desejo de poder; em terceiro lugar, faz da história da humanidade uma eterna luta pelo poder; em quarto lugar, não procura conciliar política e moral. É preciso reconhecer que Morgenthau não passa de uma leitura muito específica sobre a constituição do mundo, uma leitura ocidental, portanto, parcial. Apesar de Morgenthau ser um valioso 
patrimônio da história do pensamento internacional, trata-se apenas de mais um "regime de verdade".

\section{CONSIDERAÇÕES FINAIS}

A proposta de resgatar Zoroastro é justamente a de encontrar alternativas aos princípios rígidos que constituem o fundamento básico da teoria de Relações Internacionais. Zoroastro pode ajudar a refazer uma apreciação sobre a natureza humana, seus anseios e suas possibilidades, desfazendo a impressão de que ela tem como atributo essencial o desejo de poder; aliás, pelo contrário, na doutrina de Zoroastro, os homens, em sua natureza, também podem ser bons, morais e justos, desde que saibam aplicar as virtudes práticas no seu dia-a-dia. Ora, se de acordo com a primeira imagem das relações internacionais, o local das causas importantes da guerra residem na natureza e no comportamento do homem, a eliminação desta tem que vir da elevação e do esclarecimento ou de medidas que assegurem seu reajustamento psicossocial (Cf. WALTZ, 2004, p. 23). De acordo com a citação, podemos supor, aliás, seguindo KennethWaltz - que a causa da guerra não passa da não-vivência mais ampla de princípios como àqueles estipulados por Zoroastro, vale lembrar: boas palavras, boas condutas, bons pensamentos.

Naturalmente, ao tempo de Zoroastro, não haviam "relações internacionais" como entendidas hoje e sua doutrina não surgiu nem foi destinada ao estudo do sistema de estados. Porém, ela nos oferece uma leitura da natureza humana e da constituição do mundo, algo que Morgenthau também ofereceu e precisou conceber antes de pensar sua teoria das Relações Internacionais. Essa pesquisa não propõe Zoroastro como rival de Morgenthau, o que seria impossível e incoerente. O que se deseja é encontrar em outra tradição novas visões sobre a constituição da realidade, de tal modo que se possa enriquecer o manancial crítico sobre as teorias vigentes e servir como apoio para todos àqueles que desejam compreender melhor as próprias limitações existentes nas leituras ocidentais do mundo, que, aliás, vem marcando o curso da história do pensamento sobre política internacional.

A tarefa de revisão ontológica envolve um processo de desconstrução das ontologias aceitas até aqui. O processo inicia com a negação das tendências e teorias dominantes; pois, "como não podemos conhecer o futuro, não podemos dar um nome 
satisfatório às estruturas futuras; só podemos denominá-las em termos de negação, ou negação potencial, das tendências dominantes que são do nosso conhecimento" (COX In: ROSENAU; CZEMPIEL, 2000: p. 193). Negar os pressupostos ontológicos não significa difundir um ceticismo estéril; apenas significa que será construído um processo reflexivo dentro do qual uma fase passada do pensamento é suspensa, isto é, um discurso anterior é anulado, mas preservado na fase seguinte, após sua desconstrução (Cf. COX In: ROSENAU; CZEMPIEL, 2000: p. 193). Na verdade, o processo de desconstrução das ontologias vigentes é um processo de transformação do conhecimento. Esse desafio tem por objetivo oferecer uma nova perspectiva de um mesmo tópico, tema ou problema. Cox (In: ROSENAU; CZEMPIEL, 2000), por exemplo, para repensar a noção de história e progresso proporá um retorno ao pensamento de IbnKaldun (1332-1406), pensador, político e diplomata islâmico. Ele faz isso anulando os conceitos de progresso e evolução presentes na epistemologia positivista/iluminista para, no retorno a Kaldun, repensar os mesmos conceitos de progresso e evolução, mas agora, sob os termos de um pensador islâmico. O movimento metodológico dessa pesquisa assemelha-se ao procedimento adotado por Cox: ele propõe a suspensão de algum princípio discursivo vigente na teoria de Relações Internacionais para analisar o mesmo princípio sob uma nova ótica, nesse caso, uma ótica não-ocidental. 


\section{REFERÊNCIAS BIBLIOGRÁFICAS}

ABRI-ISA 2009. Disponível em: [http://abriisa2009.wordpress.com/]. Acesso em: set. 2012.

ADGHIRNI, Samy. Os iranianos. São Paulo: Editora, Contexto, 2014.

ASHLEY, R (1996). The achievements of post-structuralism In: SMITH, S.; BOOTH, K.; ZALEWSKI, M. (eds.) International theory: positivism and beyond. Cambridge: Cambridge University Press, 1996.

ASHWORTH, Lucian. Did the realist-idealist Great Debate really happen? International Relations, 16:13, 2002

BURCHILL, Scott. Introduction. In: Theories of International Relations. London: MacMillan, 1996

BOYCE, Mary. A history of zoroastrianism. The early period. New York: E.J. Brill, 1989.

CANÇADO TRINDADE, Antonio Augusto. O Direito Internacional em um Mundo em Transformação. Rio de Janeiro: Editora Renovar, 2002.

COX, Robert (1992), Rumo a uma conceituação pós-hegemônica da ordem mundial: reflexões sobre a relevância de Ibn Kaldun In: ROSENAU, James N.; CZEMPIEL, Ernst-Otto (orgs.). Governança sem governo: ordem e transformação na política mundial. Tradução de Sérgio Bath. Brasília: Editora Universidade de Brasília, 2000.

DEVETAK, Richard (2005). Critical Theory In: BURCHILL, S.; LINKLATER, A.; DEVETAK, R. (et. Alli). Theories of International Relations. New York: Palgrave, 2005.

DUCHESNE-GUILLEMIN, J. La religion de l'Iran ancient. Paris: P.U.F, 1992.

HASLAM, Jonathan. A necessidade é a maior virtude. O pensamento realista nas relações internacionais. Trad. Waldéa Barcellos. São Paulo: Martins Fontes, 2006.

HEILBRONER, Robert; MILBERG, William The Crisis of Vision in Modern Economic Thought. Cambridge: Cambridge University Press, 1995.

HERÓDOTO. História. São Paulo: Ediouro, 2001, pp. 376-382.

HIRSCHMAN, Albert O. A Economia como Ciência Moral e Política. Editora Brasiliense, São Paulo, 1986.

IQBAL, Muhammad. The development of metaphysics in Persia. A contribution to the history of muslim philosophy. London: London Luzac and Company, 1908. 
KAPADIA, S. A. The teachings of zoroaster and the philosophy of the parsi religion. London: John Murray, 1905.

KELLENS, J. La cosmogonie mazdéenne ancienne. Huttes cosmiques en Iran. Liege: Les Civilisations Orientales, 1990.

MEASHEIMER, J.J. The tragedy of great power politics. New York: W.W Norton \& Company, 2001.

MORGENTHAU, Hans. A política entre as nações: aluta pelo poder e pela paz. Trad. Oswaldo Biato. Brasília: Editora da Universidade de Brasília, Instituto de Pesquisa de Relações Internacionais; São Paulo: Imprensa Oficial do Estado, 2003.

NIEBUHR, Reinhold. Moral man \&Immoral society. A study in ethics and politics. Kentucky: Westminster John Knox Press, 2001.

OLIVEIRA, Silvio Luiz de. Tratado de Metodologia Científica. 2. ed. São Paulo: Pioneira, 1999.

ROCHA, Antônio Jorge Ramalho. Relações Internacionais: teorias e agendas. Brasília: IBRI e FUNAG, 2002. Caps. 1 e 2.

ROSE, Jenny. Zoroastrianism. London: I.B. Taurus, 2011.

SMITH, S. (1996). Positivism and beyond In: SMITH, S.; BOOTH, K.; ZALEWSKI, M. (eds.) International theory: positivism and beyond. Cambridge: Cambridge University Press, 1996.

SKLAERVO, Oktor (2005). Introduction to Zoroastrianism.Disponível em: [http://www.fas.harvard.edu/ iranian/Zoroastrianism/]. Acesso em: mar. 2016.

TUCÍDIDES. História da guerra do peloponeso. Trad. Mário da Gama Kury. Brasília: Editora Universidade de Brasília, Instituto de Pesquisa de Relações Internacionais; São Paulo: Imprensa Oficial do Estado de São Paulo, 2001.

WALLERSTEIN, Immanuel. O universalismo europeu: a retórica do poder. São Paulo: Boitempo Editorial, 2007.

WALTZ, Kenneth. Teoria das relações internacionais. Trad. Maria Luísa Felgueiras Gayo. Lisboa: Gradiva, 2002.

. O homem, o estado e a guerra. Uma análise teórica.

Trad.AdailUbirajaraSobral. São Paulo: Martins Fontes, 2004.

WENDT, Alexander. Anarchy is what states make of it: the social construction of power politics. International Organization, vol. 46, no. 2, Spring 1992.

WIESEHÖFER, J. Ancient Persia from 550 BC to 650 AD. London and New York: I. B. Taurus, 1996.

ZOROASTRO.Yasna In: SKJAERVO, Oktor (2007).Zoroastriantexts. Disponível em: [http://www.fas.harvard.edu/ iranian/Zoroastrianism/]. Acesso em: mar. 2016. 
YashtIn: SKJAERVO, Oktor (2007). Zoroastriantexts. Disponível em: [http://www.fas.harvard.edu/ iranian/Zoroastrianism/]. Acesso em: mar. 2016.

VidevdadIn: SKJAERVO, Oktor (2007). Zoroastrian texts.Disponível em: [http://www.fas.harvard.edu/ iranian/Zoroastrianism/]. Acesso em: mar. 2016. 